\title{
PERDARAHAN POSTPARTUM (PERDARAHAN PASKASALIN)
}

\author{
Leo Simanjuntak ${ }^{1}$ \\ Fakultas Kedokteran Universitas HKBP Nommensen \\ Email: leosimanjuntak@gmail.com
}

\begin{abstract}
Postpartum hemorrhage is the leading cause of maternal death worldwide with $5-10 \%$ of incidence. The etiology of postpartum hemorrhage are uterine atony, retensio placentae, genital tract laceration, retained placental tissue and coagulation disorders. It was estimated 2 hours period from the onset of postpartum hemorrhage toward the maternal death, meanwhile it was 12 hours in antepartum hemorrhage. It is therefor early diagnosis and prompt management is essential. The solid and skilled teamwork is needed in order to successfully manage postpartum hemorrhage and to avoid maternal death.
\end{abstract}

Keywords: Thermosyphon Loop, Heat Exchanger, R134a Refrigerant, Effectiveness, Thermal Resistance.

\begin{abstract}
Abstrak
Perdarahan postpartum merupakan penyebab utama kematian maternal diseluruh dunia dengan insiden sebesar 5\% - 10\% dari seluruh persalinan. Penyebab perdarahan postpartum meliputi atonia uteri, retensio plasenta, laserasi jalan lahir, sisa plasenta dan gangguan pembekuan darah. Estimasi waktu menuju kematian pada perdarahan pospartum diperkirakan hanya berlangsung selama 2 jam, sementara itu perdarahan antepartum membutuhkan waktu kira-kira 12 jam, oleh sebab itu sangat penting untuk mengenali lebih dini dan memberikan penanganan segera.

Kerjasama tim yang kompak dan terlatih sangat diperlukan dalam penanganan perdarahan postpartum. Untuk membentuk tim yang terlatih dalah mengatasi perdarahan postpartum, diperlukan sesi latihan dan simulasi kasus secara rutin.
\end{abstract}

Kata Kunci: Perdarahan Post-Partum; Kematian Maternal; Manajemen Tim.

\section{PENDAHULUAN}

\subsection{Latar Belakang Masalah}

Perdarahan masih merupakan masalah utama dalam bidang obstetri sampai saat ini. Bersama-sama dengan preeklampsia/eklampsia dan infeksi merupakan trias penyebab kematian maternal utama baik dinegara maju maupun dinegara sedang berkembang.

Angka kematian ibu di Indonesia masih tinggi yaitu sebesar 305/100.000 lahir hidup pada tahun 2015, menurun dibandingkan tahun 2012 sebesar 359 /100.000 lahir hidup tetapi meningkat dibandingkan tahun 2007 yaitu 228/100.000 lahir hidup. Penyebab utama kematian maternal adalah perdarahan postpartum (Postpartum 
haemorrhage) (PPH) atau perdarahan paskasalin (PPS), dikuti preeklampsia/eklampsia dan infeksi (Gambar 1).

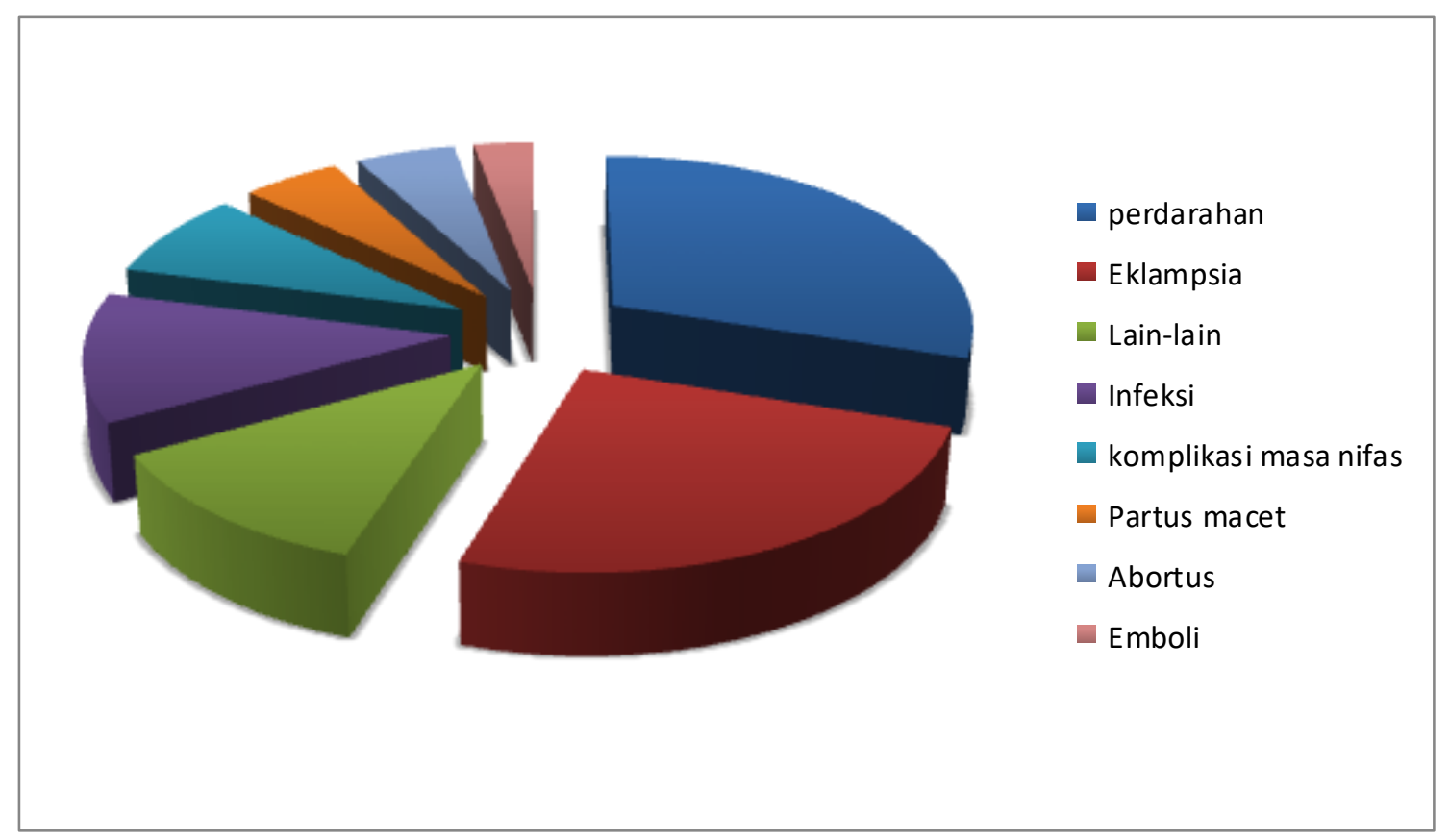

Gambar 1. Penyebab Kematian Maternal

Pada gambar 1 diatas dapat dilihat secara umum penyebab kematian maternal adalah perdarahan $30 \%$, eklampsia $25 \%$, infeksi $12 \%$, komplikasi masa nifas $8 \%$, abortus 5\%, partus macet 5\%, emboli 3\% dan penyebab lainnya $12 \%$. Perdarahan postpartum merupakan penyebab utama kematian maternal diseluruh dunia dengan insidens sebesar 5\% - 10\% dari seluruh persalinan.

Estimasi waktu menuju kematian pada perdarahan pospartum diperkirakan hanya berlangsung selama 2 jam, sementara itu perdarahan antepartum membutuhkan waktu kira-kira 12 jam, oleh sebab itu sangat penting untuk mengenali lebih dini dan memberikan penanganan segera. Terdapat kecenderungan penurunan kematian maternal oleh karena perdarahan hal ini disebabkan antara lain penanganan yang semakin baik tetapi angka ini seharusnya masih bisa diturunkan lebih rendah lagi.

Trias keterlambatan sudah lama diketahui menjadi penyebab terjadinya kematian maternal yaitu terlambat merujuk, terlambat mencapai tempat rujukan, dan terlambat mendapat pertolongan yang adekuat di tempat rujukan. Dua faktor yang pertama sering terjadi di negara-negara berkembang. Sedangkan faktor ketiga bisa 
terjadi baik di negara berkembang maupun di negara maju. The Confidential Enquiries menekankan bahwa kematian karena PPH disebabkan "too little done \& too late", oleh karena itu PPH merupakan komplikasi obstetri yang menjadi masalah. Selain mortalitas maternal, morbiditas maternal akibat kejadian PPH juga cukup berat, sebagian bahkan menyebabkan cacat menetap berupa hilangnya uterus akibat histerektomi. Morbiditas lain diantaranya anemia, kelelahan, depresi, dan risiko tranfusi darah. Histerektomi menyebabkan hilangnya kesuburan pada usia yang masih relatif produktif sehingga dapat menimbulkan konsekuensi sosial dan psikologis. Selain itu, telah diketahui bahwa PPH yang masif dapat mengakibatkan nekrosis lobus anterior hipofisis yang menyebabkan sindroma Sheehan's.

\section{Hemostasis postpartum}

Pada kehamilan cukup bulan sedikitnya $600 \mathrm{ml} / \mathrm{mnt}$ darah mengalir keuterus melalui ruang-ruang interviler plasenta. Darah masuk melalui arteri spiralis yang berjumlah sekitar 120, dan arteri spiralis ini tidak memiliki lapisan muskularis akibat adanya remodeling oleh invasi trofoblast. Apabila terjadi pelepasan plasenta pada kala III persalinan maka arteri spiralis akan terbuka sehingga terjadi perdarahan. Kontraksi uterus akan menjepit arteri spiralis yang terbuka sehingga perdarahan berhenti. Selanjutnya diikuti terbentuknya bekuan-bekuan darah yang menyumbat lumen arteri spiralis. Sebaliknya apabila tidak terjadi kontraksi uterus segera setelah pelepasan plasenta akan terjadi perdarahan postpartum yang hebat dan membahayakan jiwa.

\section{Definis perdarahan postpartum}

Sejak lama perdarahan postpartum diartikan sebagai kehilangan darah $500 \mathrm{ml}$ atau lebih setelah janin dan plasenta lahir (akhir kala III) pada persalinan pervaginam atau $1000 \mathrm{ml}$ atau lebih pada persalinan seksio sesarea. Definisi ini dirasakan terlalu sederhana apabila dikaitkan dengan adanya pertambahan volume plasma darah yang normal pada kehamilan yaitu rata-rata sebesar $30-60 \%$ atau $1500-2000 \mathrm{ml}$ selama kehamilan. Oleh karena itu pengukuran kadar hematokrit sangat penting menilai jumlah perdarahan yang terjadi selain pengukuran secara kwantitatif. Secara umum diterima apabila kadar hematokrit turun sebesar 3\% itu berarti sudah terjadi kehilangan darah sebanyak pertambahan volume darah kehamilan normal (30-60\%) ditambah dengan 500 
$\mathrm{ml}$.

\section{Etiologi perdarahan postpartum}

Penyebab perdarahan postpartum dapat dibagi menjadi $4 \mathrm{~T}$ yaitu tone (tonus; atonia uteri), tissue (jaringan; retensio plasenta dan sisa plasenta), tears (laserasi; laserasi perineum, vagina, serviks dan uterus) dan thrombin (koagulopati; gangguan pembekuan darah). Atonia uteri merupakan penyebab utama perdarahan postpartum yaitu sebesar $70 \%$ dan sekaligus penyebab utama kematia maternal. Trauma seperti laserasi, ruptura uteri dll. sebesar 20\%, tisuиe (jaringan) seperti retensio plasenta, sisa plasenta sebesar 10\% serta thrombin (koagulopati) atau gangguan pembekuan darah seperti idiopathic thrombocytopenic purpura (ITP), thombotic thrombocytopenic purpura, penyakit von Willebrand dan hemofilia, menyumbang $1 \%$ sebagai penyebab PPH.

\section{Klasifikasi perdarahan postpartum.}

Perdarahan dibagi menjadi minor yaitu 500-1000 $\mathrm{ml}$ atau mayor >1000 $\mathrm{ml}$. Perdarahan mayor dapat dibagi menjadi sedang yaitu 1000-2000 $\mathrm{ml}$ atau berat $>2000$ ml Pembagian lain menurut Sibai adalah perdarahan ringan (mild) apabila jumlah perdarahan $\leq 1500 \mathrm{ml}$, berat (severe) $>1500 \mathrm{ml}$, dan massif $>2500 \mathrm{ml}$.

Berdasarkan waktu terjadinya dibagi menjadi perdarahan postpartum primer $\{$ primary post partum haemorrhage) yaitu perdarahan yang terjadi dalam 24 jam pertama postpartum, sedangkan sekunder (secondary post partum haemorrhage) merupakan perdarahan yang terjadi setelah periode 24 jam sampai 6 minggu postpartum. Penyebab utama perdarahan postpartum adalah atonia uteri.

Tabel 1. Klasifikasi Perdarahan Postpartum Berdasarkan Jumlah Perdarahan

\begin{tabular}{|c|c|c|c|c|}
\hline Klasifikasi & $\begin{array}{c}\text { Perkiraan } \\
\text { perdarahan } \\
(\mathrm{ml})\end{array}$ & $\begin{array}{c}\text { Persentase } \\
\text { perdarahan } \\
(\%)\end{array}$ & Tanda \& gejala klinis & Tindakan \\
\hline 0 (normal) & $<500$ & $<\mathbf{1 0}$ & Tidak ada & \\
\hline \multicolumn{5}{|c|}{ Garis waspada } \\
\hline 1 & $\mathbf{5 0 0 - 1 0 0 0}$ & $<\mathbf{1 5}$ & Minimal & $\begin{array}{c}\text { Perlu } \\
\text { pengawasan }\end{array}$ \\
\hline
\end{tabular}

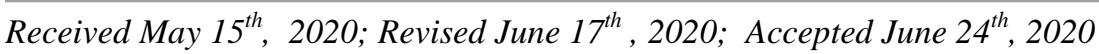




\begin{tabular}{|c|c|c|c|c|}
\hline & & & & $\begin{array}{c}\text { ketat dan } \\
\text { terapi cairan } \\
\text { infus }\end{array}$ \\
\hline 2 & $1200-1500$ & $20-25$ & $\begin{array}{c}\text { Frekuensi nadi halus } \\
\text { Hipotensi postural }\end{array}$ & $\begin{array}{c}\text { Terapi cairan } \\
\text { infus dan } \\
\text { uterotonika }\end{array}$ \\
\hline 3 & $\mathbf{1 8 0 0 - 2 1 0 0}$ & $30-35$ & $\begin{array}{c}\text { Garis bertindak } \\
\text { Akral dingin } \\
\text { Takipnu }\end{array}$ & $\begin{array}{c}\text { Manajemen } \\
\text { aktif agresif }\end{array}$ \\
\hline 4 & $>2400$ & $>40$ & Syok & $\begin{array}{c}\text { Manajemen } \\
\text { aktif kritikal } \\
\text { (risiko 50\% } \\
\text { mortalitas } \\
\text { bila tidak } \\
\text { ditatalaksana } \\
\text { aktif) }\end{array}$ \\
\hline
\end{tabular}

\section{Pengelolaan dan Penatalaksanaan}

Manajemen aktif persalinan kala tiga terbukti mencegah terjadinya perdarahan postpartum. Manajemen aktif persalinan kala tiga terdiri dari tiga tindakan yaitu injeksi oksitosin segera setelah bayi lahir, penegangan tali pusat terkendali, dan masase uterus pasca kelahiran plasenta.

Prosedur penanganan perdarahan postpartum dapat disingkat dengan HAEMOSTASIS (Tabel 2). Tatalaksana ini terdiri dari tatalaksana awal diantaranya meminta bantuan, memasang jalur intravena dengan kateter ukuran besar, mencari etiologi dan melakukan masase uterus. Langkah selanjutnya yaitu memberikan obatobatan berupa preparat uterotonika, diantaranya oksitosin, metilergometrin, dan misoprostol. Oksitosin diberikan 10-20 unit dalam $500 \mathrm{~mL} \mathrm{NaCl} \mathrm{0,9 \%} \mathrm{atau} 10$ unit intramuskular. Misoprostol merupakan analog prostaglandin $\mathrm{E}_{1}$ diberikan dengan dosis 600-1000 mcg dengan rute pemberian per oral, rektal atau vaginal.

Setelah memberikan obat-obatan, langkah selanjutnya adalah memberikan tatalaksana konservatif non bedah, seperti menyingkirkan faktor sisa plasenta atau robekan jalan lahir, melakukan kompresi bimanual atau kompresi aorta abdominal, 
serta memasang tampon uterus vagina dan kondom kateter. Langkah selanjutnya dari tatalaksana perdarahan postpartum adalah melakukan tatalaksana konservatif bedah, yakni metode kompresi uterus dengan teknik B-Lynch, devaskularisasi sistem perdarahan pelvis, atau embolisasi arteri uterina dengan radiologi intervensi. Langkah terakhir adalah melakukan histerektomi subtotal atau total.

WHO membuat rekomendasi penanganan perdarahan postpartum yang kurang lebih sama dengan langkah HAEMOSTASIS. Berikut penjabaran praktis upaya tatalaksana perdarahan postpartum dan persiapan rujukan pada berbagai kondisi :

Tabel 2. Langkah HAEMOSTASIS untuk tatalaksana perdarahan postpartum

\begin{tabular}{|c|c|c|}
\hline MNEMONIC & & \\
\hline $\mathbf{H}$ & Meminta pertolongan & Langkah awal \\
\hline $\mathbf{A}$ & $\begin{array}{l}\text { Akses vena dengan kateter ukuran besar } \\
\text { (18G) dan infus kristaloid ( } \mathrm{NaCl} 0,9 \% \\
\text { atau Ringer Laktat) serta transfusi }\end{array}$ & \\
\hline $\mathbf{E}$ & Etiologi dan preparat uterotonik & \\
\hline $\mathbf{M}$ & Masase uterus & \\
\hline $\mathbf{O}$ & Preparat uterotonik dan misoprostol & Obat-obatan \\
\hline $\mathbf{S}$ & $\begin{array}{l}\text { Persiapan kamar operasi. Singkirkan } \\
\text { faktor sisa plasenta, robekan jalan lahir, } \\
\text { kompresi bimanual, dan kompresi aorta } \\
\text { abdominal }\end{array}$ & Konservatif non-bedah \\
\hline $\mathbf{T}$ & Tampon uterus vagina, kondom kateter & \\
\hline $\mathbf{A}$ & $\begin{array}{l}\text { Kompresi uterus (bedah), teknik B- } \\
\text { Lynch }\end{array}$ & Konservatif bedah \\
\hline
\end{tabular}

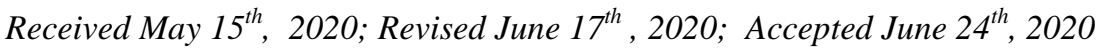




\begin{tabular}{|c|l|l|}
\hline $\mathbf{S}$ & $\begin{array}{l}\text { Devaskularisasi sistem perdarahan } \\
\text { pelvis :Lasobudiman, a. Uterina, a. } \\
\text { Ovarika, a. Hipogastrika }\end{array}$ & \\
\hline $\mathbf{I}$ & $\begin{array}{l}\text { Embolisasi a.Uteri dengan radiologi } \\
\text { intervensi }\end{array}$ & \\
\hline $\mathbf{S}$ & Histerektomi subtotal/total & Last effort/langkah akhir \\
\hline
\end{tabular}

\section{Pemantauan dan Manajemen Tim}

Pemantauan yang tepat dan pengenalan dini serta usaha pencegahan agar tidak terjadi perburukan pada kasus perdarahan postpartum sangat diperlukan. Ada beberapa sistem skoring tanda klinis yang dapat digunakan sebagai tanda peringatan untuk memprediksi peristiwa kritis yang tidak diharapkan, diantaranya national early warning score (NEWS) atau modified obstetric warning scoring system (MEOWS).

Berdasarkan skor yang didapat, akan ditentukan frekuensi pemantauan serta respon yang diperlukan. Berikut ialah sistem skoring NEWS :

\section{Gambar 2. National Early Warning Score (NEWS)}

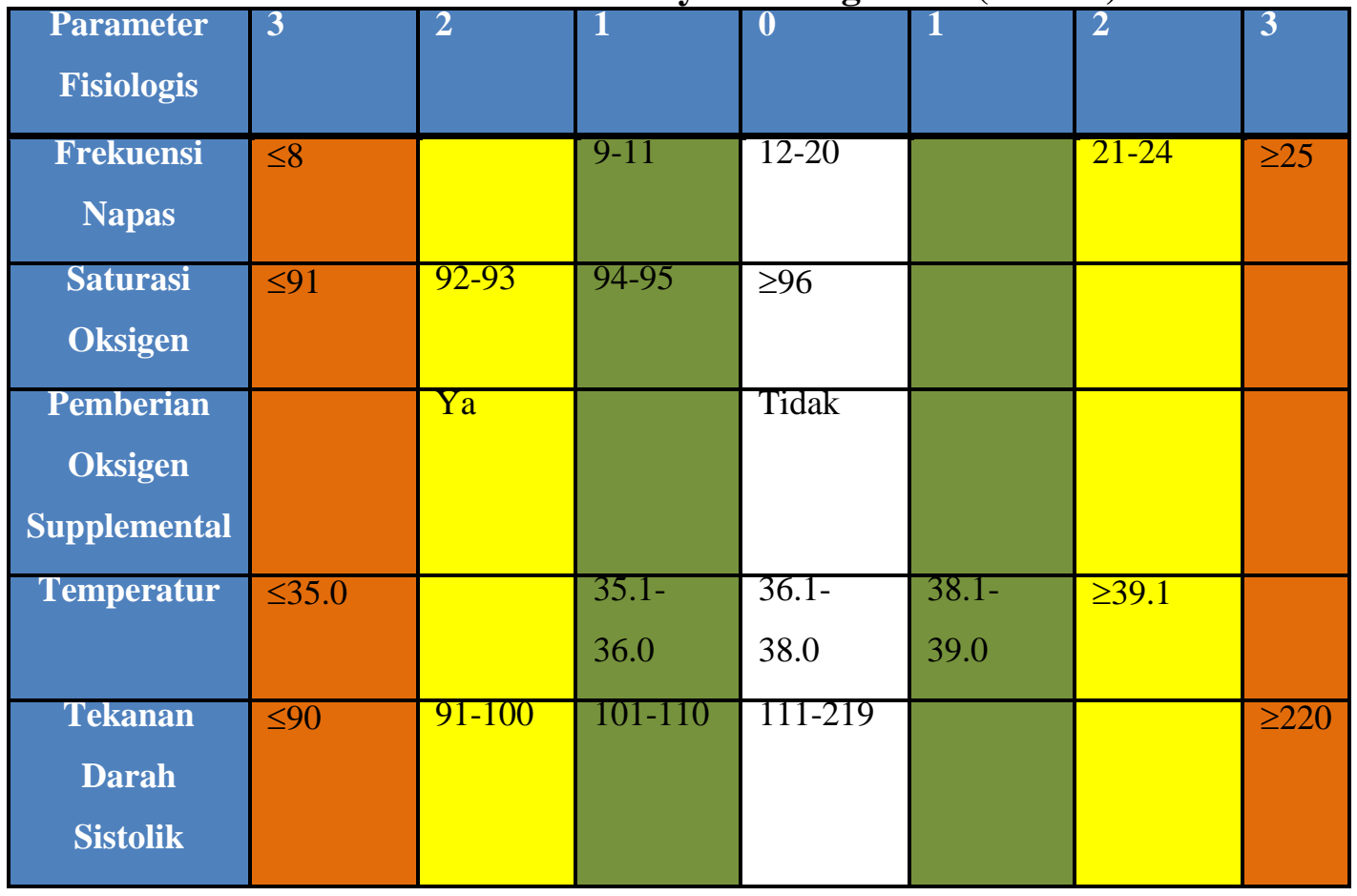

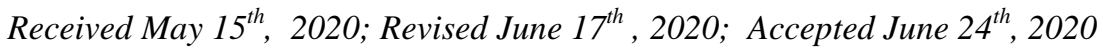




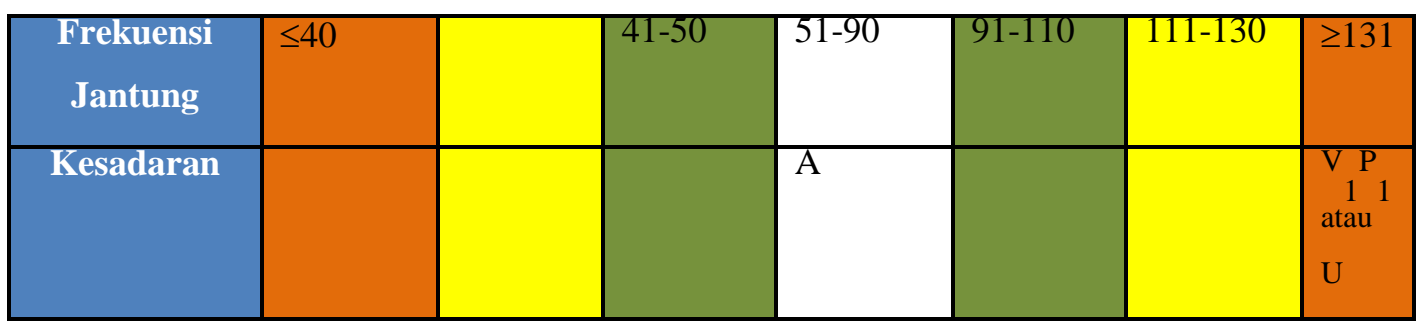

Tabel 3. Hasil skoring NEWS dan aktivasi respon

\begin{tabular}{|l|l|l|}
\hline Skor NEWS & Frekuensi Pemantauan & Respon \\
\hline 0 & Minimal setiap 12 jam & $\begin{array}{l}\text { Lanjutkan pemantauan rutin } \\
\text { NEWS }\end{array}$ \\
\hline Total 1-2 & Minimal setiap 4-6 jam & $\begin{array}{l}\text { Peringatkan perawat untuk } \\
\text { melakukan penilaian pada } \\
\text { pasien } \\
\text { Perawat memutuskan untuk } \\
\text { meningkatkan frekuensi } \\
\text { pemantauan atau perlu } \\
\text { perawatan khusus }\end{array}$ \\
\hline $\begin{array}{l}\text { Total } \geq 5 \text { atau skor } 3 \text { pada } \\
\text { salah satu parameter }\end{array}$ & $\begin{array}{l}\text { Tingkatkan frekuensi } \\
\text { pemantauan menjadi setiap } \\
\text { jam }\end{array}$ & $\begin{array}{l}\text { Perawat memanggil dokter } \\
\text { yang kompeten dalam kasus } \\
\text { akut untuk menilai pasien. } \\
\text { Perawatan khusus dengan } \\
\text { menambah alat monitor }\end{array}$ \\
\hline Total $\geq 7$ & $\begin{array}{l}\text { Pemantauan tanda vital } \\
\text { secara kontinyu }\end{array}$ & $\begin{array}{l}\text { Perawat segera memanggil } \\
\text { tim yang kompeten dalam } \\
\text { kasus kritis (termasuk } \\
\text { kemampuan intubasi atau } \\
\text { manajemen jalan napas) } \rightarrow \\
\text { Perawatan HCU/ICU }\end{array}$ \\
\hline
\end{tabular}

Kerjasama tim yang kompak dan terlatih sangat diperlukan dalam penanganan perdarahan postpartum. Untuk membentuk tim yang terlatih dalah mengatasi perdarahan postpartum, diperlukan sesi latihan dan simulasi kasus secara rutin..

Berkaitan dengan manajemen risiko perdarahan postpartum, maka setiap institusi pelayanan kesehatan maternal perlu memiliki kebijakan dan prosedur untuk kasus perdarahan postpartum.

Kebijakan dan prosedur ini meliputi :

1. Keseragaman kebijakan untuk deteksi dini dan pemantauan perdarahan postpartum 
2. Pertimbangkan sumber daya yang tersedia :

i. Rumah sakit rural (protokol dasar)

- Kriteria untuk rujukan segera dan cara komunikasi

- Manuver atau prosedur sementara untuk stabilisasi

ii. Rumah sakit sekunder

iii. Rumah sakit tersier

3. Mengidentifikasi tim multidisiplin

i. Dokter spesialis obstetri dan ginekologi, spesialis anestesi, spesialis lainnya

ii. Perawat dan bidan

iii. Bank darah, spesialis hematologi

iv. Pendidikan dan pelatihan secara teratur (drill)

4. Siklus audit untuk membandingkan pelayanan di lapangan dengan standar yang seharusnya diterapkan.

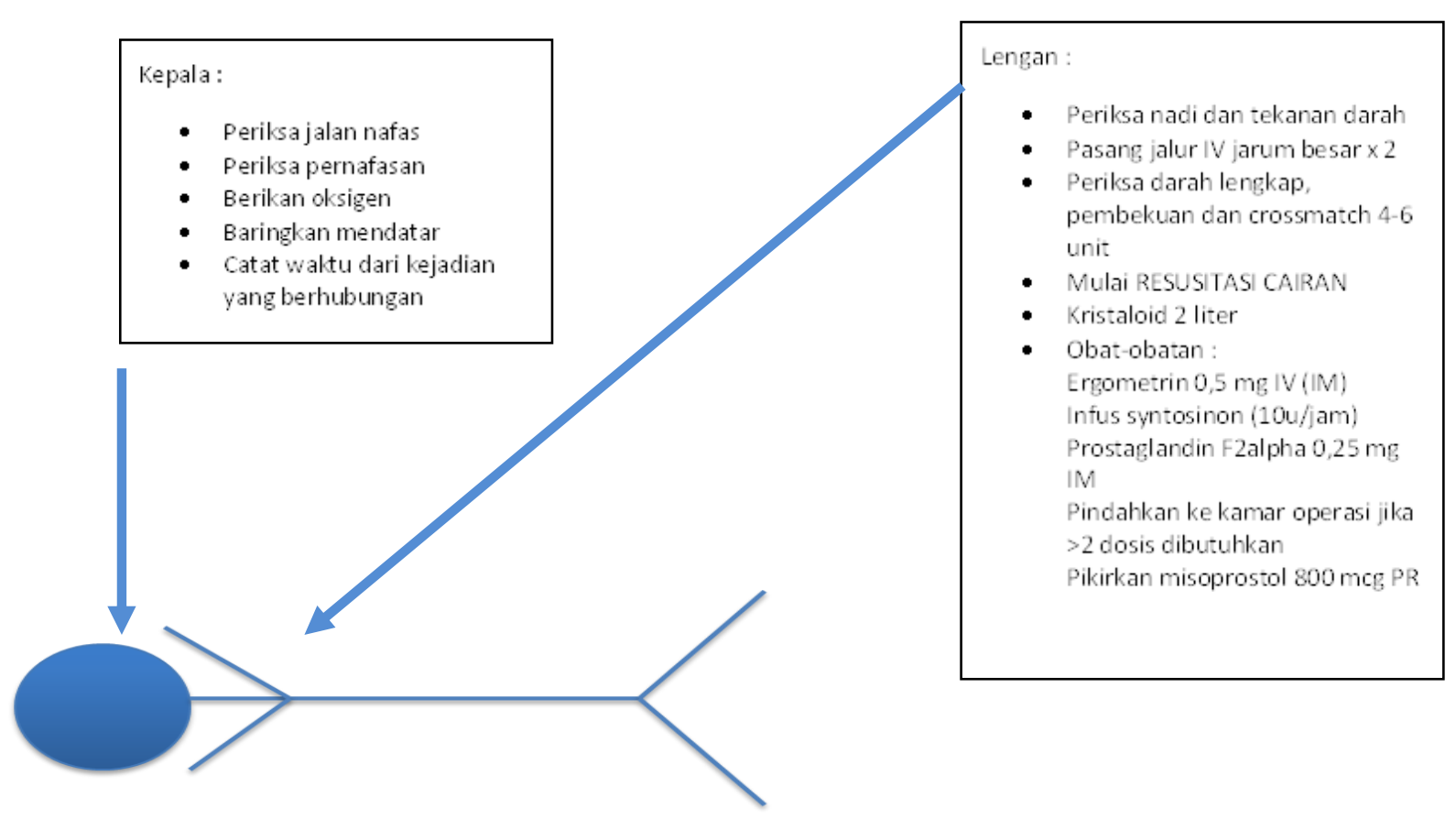

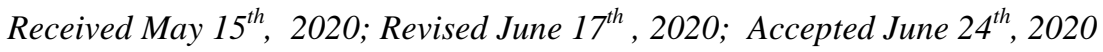




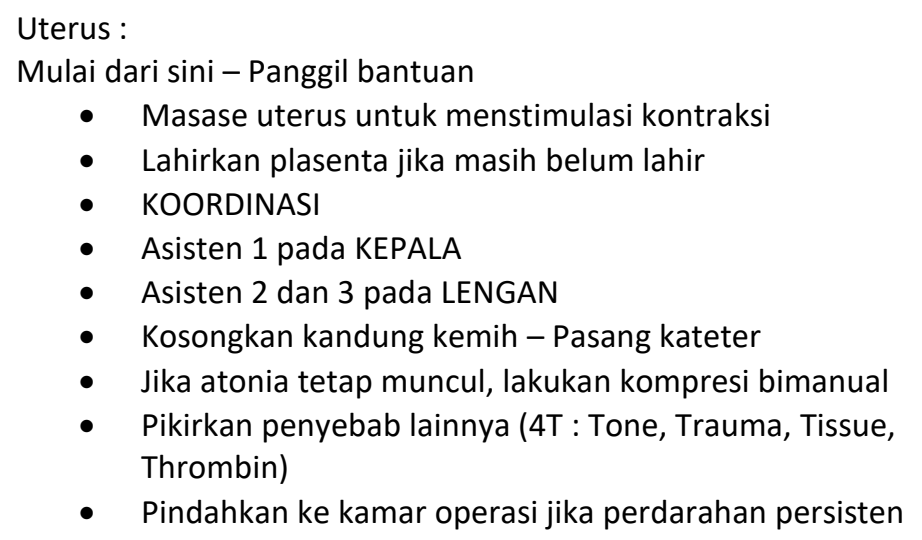

\section{DAFTAR PUSTAKA}

Sibai, BM, 2011, Management of Acute Obstetric Emergencies, Elsevier Saunders.

Saroyo, YB, 2019, Management of PPH Emergency (Latest Update), Proceeding Book PIT POGI Surabaya 2019 in Collaboration with AOFOG.

Pedoman Nasional Pelayanan Kedokteran Perdarahan Pasca-Salin, Perkumpulan Obstetri dan Ginekologi Indonesia Himpunan Kedokteran Feto Maternal 2016. Cunningham, FG, Leveno, KJ, Bloom, SL, Hauth, JC, Rouse, DJ \& Spong, CY 2014: Williams Obstetrics 24th. ed. McGraw Hill Medical pp. 780 - 861.

Poggi, SBH, Postpartum Hemorrhage \& the Abnormal Puerperium in Decherney AH, Nathan L,Laufer N, Roman AS, Eds. 2013, Current Diagnosis \& Treatment $11^{\text {th }}$ edition, The MacGaw-Hill.

Gynecologists RCoOa, RCOG Green-top Guideline, Prevention and Management of Postpartum Haemorrhage, 2011.

Schellenberg ,J, 2003, Primary Postpartum Haemorrhage (PPH, August 13.

Chandraharan, E, Arulkumaran S, 2005, Management Algorith for Atonic Postpartum Haemmorrhage. JPOG May/Jun, 31(3): 106-12.

Anderson, JM, Etches, D 2007, Prevention and management of postpartum hemorrhage. Am Fam Physician,75:875-82. 